\title{
CONGENITAL SPHEROCYTOSIS IN INFANCY
}

\author{
BY \\ DAVID BURMAN \\ From the Paediatric Department, Charing Cross Hospital, London
}

(RECEIVED FOR PUBLICATION DECEMBER 12, 1957)

Neonatal jaundice and anaemia of infancy are both common diagnostic problems. Very rarely, both these symptoms may be due to congenital spherocytosis and, unless there is a known family history of the condition, their diagnosis may be very difficult. Difficulties in diagnosis were encountered in identical twins, whose case is reported here, and whose neonatal jaundice and subsequent anaemia were thought at first to be associated with prematurity. The unusual course of the anaemia (Fig. 1) subsequently revealed the correct diagnosis even in the absence of other affected members of the family.
The clinical features of these two cases, together with a further 41 previously reported cases occurring in the first year of life, are summarized later in Table 1. This table is analyzed in order to determine the characteristic features of congenital spherocytosis in infancy, and the management of these patients is discussed.

\section{Case History}

Female twins were born on March 22, 1956, to a multiparous woman after a 36-week normal pregnancy. Both were vertex presentations and the first weighed $4 \mathrm{lb} .5 \mathrm{oz}$. (1,970 g.) and the second weighed $3 \mathrm{lb} .12 \mathrm{oz}$.

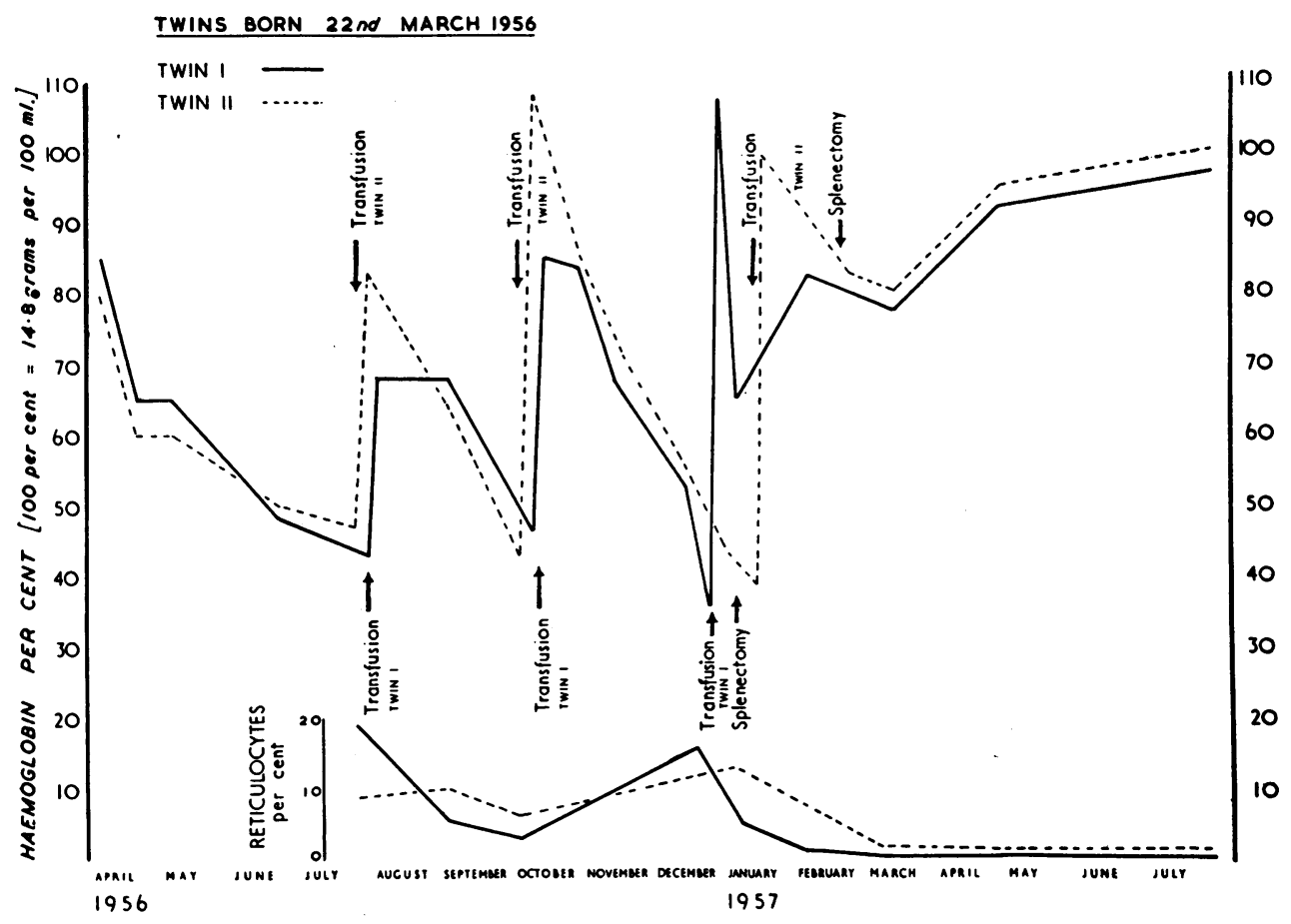

FIG. 1.-Course of anaemia in identical twins suffering from congenital spherocytosis, and progress after splenectomy. 
$(1,720 \mathrm{~g}$.). Dissection of the placenta and membranes showed that they were monochorionic. The twins appeared identical except that there was webbing of the second and third toes on the left foot in Twin 1 only. The blood groups of both are Group $\mathrm{O}, \mathrm{Rh}$ phenotype C C D ee (probable genotype CDe/CDe), $\mathrm{M} \mathrm{N}, \mathrm{S}+\mathrm{ve}$, $\mathbf{P}+$ ve, Lu - ve, K-ve, Lea + ve, Leb-ve, Fya - ve.

On March 26, both twins were noticed to be severely jaundiced and this continued until April 13. On April 5, the children appeared pale and the haemoglobin of Twin 1 was $85 \%(12.5 \mathrm{~g}$. per $100 \mathrm{ml}$.) and of Twin 2 $80 \%$ (11.8 g. per $100 \mathrm{ml}$.). By April 11 the haemoglobin had fallen to $70 \%(10.4 \mathrm{~g}$. per $100 \mathrm{ml}$.) in both twins and on April 19 was $65 \%(9.6 \mathrm{~g}$. per $100 \mathrm{ml}$.) and $60 \%$ $(8.9 \mathrm{~g}$. per $100 \mathrm{ml}$.) respectively. The twins were considered to have anaemia of prematurity associated with multiple birth. They were given ferrous sulphate from April 21, at first in doses of $\frac{1}{4}$ gr. (16 mg.) twice daily and from May $2 \frac{1}{2}$ gr. (32 mg.) was given twice daily. By June 19, Twin 1's haemoglobin had fallen to $48 \%$ (7.1 g. per $100 \mathrm{ml}$.) and Twin 2's to $50 \%(7.4 \mathrm{~g}$. per $100 \mathrm{ml}$.) and both twins had palpable spleens. They were then given $3 \frac{1}{2} \mathrm{ml}$. of Imferon (Bengers) intramuscularly during the next month. On July 24, the twins' haemoglobin levels were $45 \%(6 \cdot 7 \mathrm{~g}$. per $100 \mathrm{ml}$.) and $42 \%(6 \cdot 2 \mathrm{~g}$. per $100 \mathrm{ml}$.) respectively.

The twins were admitted to hospital from July 24 until August 4. Investigations on Twin 1, who weighed 10 lb. 3 oz. (4,660 g.), showed haemoglobin, $43 \%$ (6. 4 g. per $100 \mathrm{ml}$.); packed cell volume, $19 \cdot 5 \%$; mean corpuscular haemoglobin concentration, $32 \%$; mean cell diameter (halometer) 6.8 microns; the red blood cells showed marked anisocytosis, poikilocytosis and polychromasia; reticulocytes, 19\%; and normoblasts, 10 per 100 nucleated cells. The urine contained no bile salts and no excess urobilinogen. Two intramuscular injections of $1 \mathrm{ml}$. each of Imferon were given and on August 1 a blood transfusion of $160 \mathrm{ml}$. of whole blood. The haemoglobin on August 2 was $68 \%$ (10.1 g. per $100 \mathrm{ml}$.).

Investigations on Twin 2, who weighed $10 \mathrm{lb} .1 \mathrm{oz}$. (4,600 g.), showed haemoglobin, $47 \%$ (7 g. per $100 \mathrm{ml}$.); packed cell volume, $18 \%$; mean corpuscular haemoglobin concentration, $34 \cdot 4 \%$; the red blood cells showed marked anisocytosis, poikilocytosis and polychromasia; reticulocytes, 9\%; normoblasts, 10 per 100 nucleated cells; in a red cell fragility test haemolysis began at $0.48 \%$ saline and was complete at $0.32 \%$ saline; serum bilirubin was $0.5 \mathrm{mg}$. per $100 \mathrm{ml}$. The urine contained no bile salts and no excess urobilinogen. Twin 2 was given two injections of $1 \mathrm{ml}$. of Imferon and on August 1 a transfusion of $160 \mathrm{ml}$. of whole blood. On August 2, her haemoglobin was $83 \%(12 \cdot 3 \mathrm{~g}$. per $100 \mathrm{ml}$.).

On leaving hospital both twins were given ferrous sulphate gr. 1 (65 mg.) twice daily, but their spleens continued to be palpable and their haemoglobin fell progressively. They were re-admitted from October 3 to October 12. The haemoglobin level of Twin 1 was $45 \%(6.7 \mathrm{~g}$. per $100 \mathrm{ml}$.); the red blood cells $(2,530,000$ per c.mm.) showed marked anisocytosis, slight poikilocytosis, slight polychromasia, some appeared macrocytic and there were a few spherocytes; the colour index was 0.88 ; packed cell volume, $21 \%$; mean corpuscular haemoglobin concentration, $31 \%$; reticulocytes, $3 \cdot 1 \%$; normoblasts, 1 per 100 nucleated cells; the direct Coombs test was negative; serum bilirubin, $1.6 \mathrm{mg}$. per $100 \mathrm{ml}$. The urine contained no excess urobilinogen; the stools contained no occult blood and the fat content was normal. On October 6, $210 \mathrm{ml}$. of whole blood were given and the haemoglobin on October 11 was $85 \%$ (12.6 g. per $100 \mathrm{ml}$.).

Re-investigation of Twin 2, who now weighed $13 \mathrm{lb}$. 2 oz. (6 kg.), showed a haemoglobin level of $43 \%$ $(6.4$ g. per $100 \mathrm{ml}$.); the red blood cells, $2,410,000$ per c.mm., showed marked anisocytosis and poikilocytosis, moderate polychromasia and some cells appeared as polychromatic macrocytes; the colour index was 0.89 ; mean cell diameter, 7.0 microns; reticulocytes, $6.4 \%$; normoblasts, $2 \cdot 5$ per 100 nucleated cells; a direct Coombs test was negative; serum bilirubin was $1.2 \mathrm{mg}$. per $100 \mathrm{ml}$; the urine contained excess urobilinogen; stools contained no occult blood and the fat content was normal. On October 6, a transfusion of $220 \mathrm{ml}$. of whole blood was given and on October 11 the haemoglobin was $109 \%$ (16.1 g. per $100 \mathrm{ml}$.).

The haemoglobin fell progressively until the patients were admitted again on December 19. Both had palpable spleens and a further investigation of Twin 1, whose weight was $15 \mathrm{lb} .12 \mathrm{oz} .(7 \cdot 2 \mathrm{~kg}$.), showed that the haemoglobin level was $53 \%(7.8 \mathrm{~g}$. per $100 \mathrm{ml}$.); the red cells, 3,040,000 per c.mm., showed marked anisocytosis and polychromasia, moderate poikilocytosis and anisochromia and there were some spherocytes; the colour index was 0.87 ; reticulocytes, $16.7 \%$; normoblasts, 1 per 100 nucleated cells; packed cell volume, $20 \%$; mean corpuscular haemoglobin concentration, 39\%; mean cell volume $66 \mathrm{cu}$. microns, mean cell diameter (halometer) 7.0 microns, and mean cell thickness $1 \cdot 7$ microns; no sickle cells were detected; in a red cell fragility test haemolysis commenced at $0.6 \%$ saline and was complete at $0.32 \%$ saline; a direct Coombs test was negative; serum bilirubin was $1.0 \mathrm{mg}$. per $100 \mathrm{ml}$.; no urobilinogen was detected in the urine; radiographs of the skull and long bones were normal; a test for occult blood was negative on three occasions. On December 20, Twin 1's haemoglobin was 26\% (3.9 g. per $100 \mathrm{ml}$.) and she was transfused with the packed cells of 1 pint of blood. The haemoglobin rose to $108 \%$ (16 g. per $100 \mathrm{ml}$.), but fell to $65 \%(9.6 \mathrm{~g}$. per $100 \mathrm{ml}$.) by January 8, 1957. On January 9, a splenectomy was performed by Mr. A. R. Makey under general anaesthesia. After operation the haemoglobin level gradually rose until the baby's discharge on January 25 when it was $76 \%(11 \cdot 1 \mathrm{~g}$. per $100 \mathrm{ml}$.).

The further investigation of Twin 2, who then weighed $15 \mathrm{lb}$. $3 \mathrm{oz}$. (6,940 g.), showed a haemoglobin level of $52 \%(7.7$ g. per $100 \mathrm{ml}$.); the red cells, $2,480,000$ per c.mm., showed marked anisocytosis and polychromasia, moderate anisochromia and slight poikilocytosis and there were some spherocytes present; the colour index was 0.91 ; reticulocytes, $15 \cdot 2 \%$; normoblasts, 1 per 200 nucleated cells; packed cell volume, $22 \%$; mean 
corpuscular haemoglobin concentration, $35 \%$, and the mean corpuscular volume $77 \mathrm{c} \mu$; mean cell diameter (halometer), $7 \cdot 0$ microns, mean cell thickness, $2 \cdot 0$ microns; no sickle cells were detected; in a red cell fragility test haemolysis commenced at $0.56 \%$ saline and was complete at $0.32 \%$ saline; a direct Coombs test was negative; serum bilirubin was $0.8 \mathrm{mg}$. per $100 \mathrm{ml}$.; no urobilinogen was detected in the urine; radiographs of the skull and long bones were normal; a test for occult blood was negative on three occasions. On January 18 the haemoglobin level had fallen to $39 \%$ $(5.8 \mathrm{~g}$. per $100 \mathrm{ml}$.) and $300 \mathrm{ml}$. of packed blood cells were transfused prior to splenectomy. The patient developed an upper respiratory tract infection and splenectomy, together with the removal of an accessory spleen in the omentum by Mr. A. R. Makey, was postponed until February 25. Until the child's discharge from hospital the haemoglobin remained at about $80 \%$ (11.8 g. per $100 \mathrm{ml}$.).

On July 30,1957 , both twins were thriving, weighing $21 \mathrm{lb} .6 \mathrm{oz}$. $(9,770 \mathrm{~g}$.) and $20 \mathrm{lb} .1 \mathrm{oz}$. $(9,170 \mathrm{~g}$.) respectively, with a haemoglobin of $98-100 \%(14 \cdot 5-14 \cdot 8$ g. per $100 \mathrm{ml}$.) and less than $1 \%$ reticulocytes. The osmotic fragility of the red cells of both twins commenced at $0.64 \%$ saline and was complete at $0.32 \%$ saline.

Pathology of Spleens. Dr. John Shore reported that the spleens of both twins were enlarged, measuring $7 \times 4.5 \times 3.5 \mathrm{~cm}$. and $7 \cdot 5 \times 4 \cdot 7 \times 3.5 \mathrm{~cm}$. respectively; with the latter specimen an accessory spleen, $0.8 \mathrm{~cm}$. in diameter, was also received. The capsules were smooth and no abnormality was seen on the cut surfaces. The microscopical appearance of both spleens and of the accessory spleen were similar. The sinuses were filled with blood and appeared normal. A moderate amount of haemosiderin was present in macrophages in the pulp, most probably resulting from repeated blood transfusions. Scattered eosinophil and neutrophil polymorphonuclear leucocytes were also seen in the pulp. The malpighian follicles contained prominent germinal centres and also exhibited well-marked marginal zones of large and medium lymphocytes which lay between the lymphocytic mantle of many of the follicles and the pulp. Whilst not so prominent as those described in cases of hypersplenism by Leffler (1952), these zones were considerably wider than normal.

Family History. The family are all Irish and all the relatives in England were examined clinically and their haemoglobin and reticulocytes estimated and a film scanned for cells suggestive of spherocytes. The mother, father, second sister, a maternal aunt and a maternal uncle were all normal, but the oldest sister had an iron deficiency anaemia with a haemoglobin of $66 \%(9.8 \mathrm{~g}$. per $100 \mathrm{ml}$.) which has since responded to oral ferrous sulphate. In October, 1957, a pair of binovular twins were born to the parents and these appeared clinically normal with normal haemoglobin, reticulocyte counts, red cell morphology and fragility.

\section{Clinical Picture}

Table 1 shows that a family history of congenital spherocytosis was present in 25 cases and absent in 15 cases. Thus, about $60 \%$ of the cases had a positive family history but this figure is probably too low, for the relatives of some of the patients in the table were not carefully investigated. This view is contrary to the earlier opinion expressed by Abt (1940) and David and Minot (1944) that a family history is rare if symptoms are present in infancy and indeed, only two cases (Cases 14 and 30) were diagnosed under the age of 3 months in the absence of such a history. The proportion of patients without a family history, however, is sufficiently high to make congenital spherocytosis preferable to hereditary spherocytosis as the name of the disease. The cases reported in this paper are the only identical twins in the table and the course of the disease in both was remarkably similar (Fig. 1). Debré, Lamy, Sée and Schrameck (1938) have reported identical twins both affected with congenital spherocytosis at the age of 4 years and Lesné, Launay and Hurez (1935) have described binovular twins both of whom were affected.

Of the 35 cases in the table whose sex is stated, 22 were boys and 13 girls, confirming the view that the disease is not sex linked.

Neonatal jaundice was present in 23 cases, but in Cases 1, 2 and 7 this could have been accounted for by prematurity. In Cases 32 and 38 jaundice was severe enough to produce kernikterus and in Cases 33,38 and 43 it was sufficient to warrant one or more replacement transfusions. Turman, Vaughan and Shelley (1956) discovered another case with the clinical findings of kernikterus and a history of neonatal jaundice, when they investigated children attending a cerebral palsy clinic. A history of neonatal jaundice is also often obtained when cases are examined later in life (e.g. Campbell and Warner, 1926; Dawson, 1931; Bernard, Boiron and Estager, 1952). Neonatal jaundice due to congenital spherocytosis is accompanied by an erythroblastaemia and usually is present in the first few days after birth. In five cases, however, the jaundice did not appear until after the first week of life when haemolytic jaundice due to other causes is uncommon. Jaundice after the neonatal period was present in only six cases and was never a very prominent symptom. This fact supports the suggestion (Diamond, 1937) that the aphorism 'adults are more jaundiced than sick' should be revised to "children, and particularly infants, are more sick than jaundiced' provided one excludes the neonatal period.

Anaemia was present in 38 cases of the 43 in the 
SUMMARY OF PUBLISHED CASES OF CONGENITAL SPHEROC

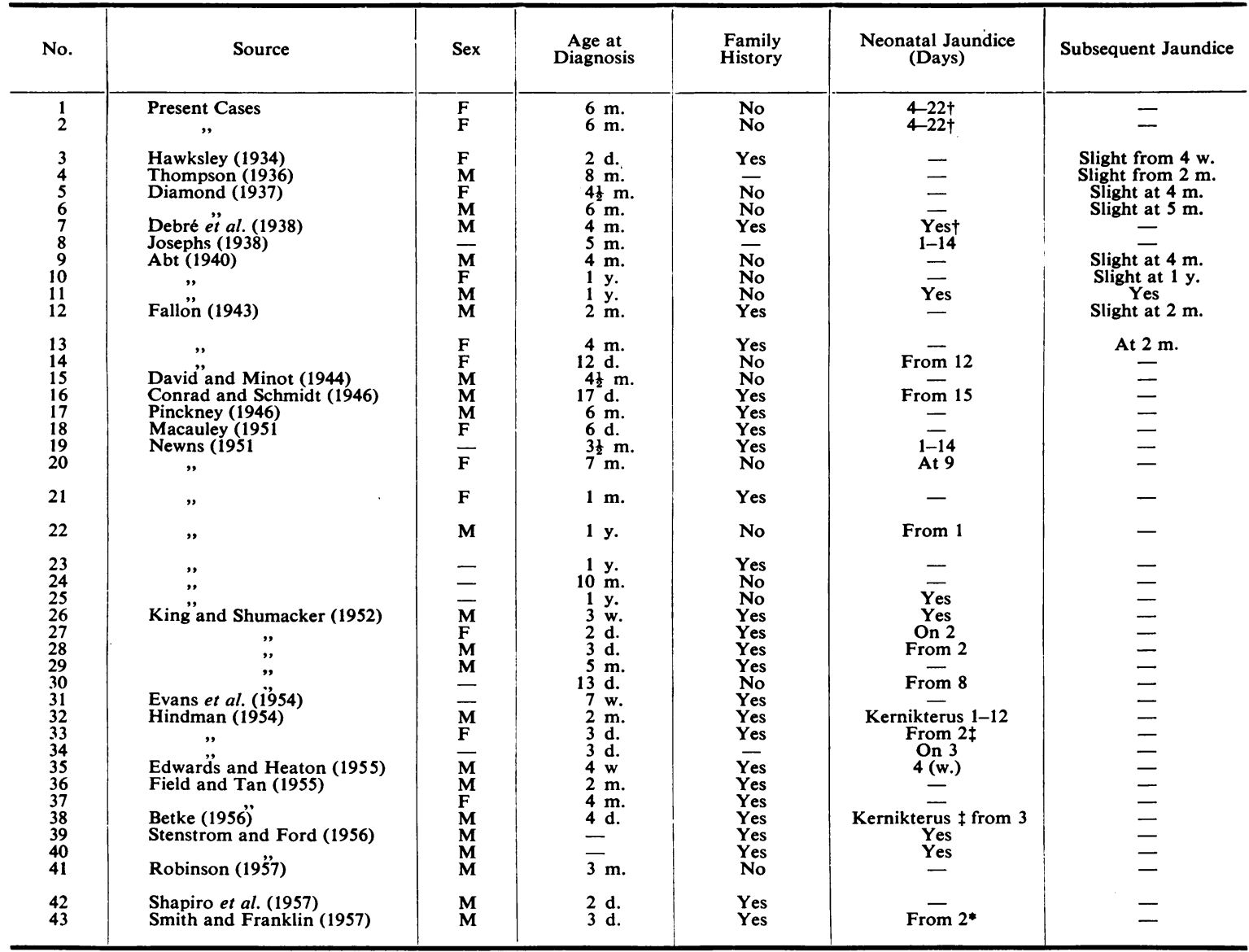

table. In a further three, splenectomy was performed in the first 15 days, and in another at 10 weeks. The remaining case (Case 43) received two replacement transfusions on the third and fourth day of life, and did not develop anaemia in the next four months. Anaemia therefore appears to be a universal symptom of congenital spherocytosis presenting in the first year of life unless splenectomy or replacement transfusions have been performed for neonatal jaundice. Many cases, however, show no symptoms at all in infancy and Lappin (1956) reports two children of a family known to suffer from congenital spherocytosis, who have had spherocytosis and increased red cell fragility since birth but who have no enlargement of the spleen and no symptoms. The anaemia tends to be severe and many of the cases have had repeated blood transfusions in the first few months of life in a similar manner to the twins described here (Fig. 1). The anaemia may commence at any time during the first year but in the first week the haemoglobin level tended to be normal in the cases investigated, although several cases were thought to have been pale at or soon after birth.

Though the information is not included in the table itself the spleen was enlarged in 36 of the 40 cases where the state of the spleen was described. Thus in infants, as well as in later life, it is uncommon to find the spleen impalpable (Dacie, 1954a).

The characteristic features of the blood examination are reticulocytosis, which was observed in $\mathbf{2 0}$ cases, and the presence of spherocytes (not detailed in the table) in 26 cases. In many cases the 
LE 1

YTOSIS DIAGNOSED DURING THE FIRST YEAR OF LIFE

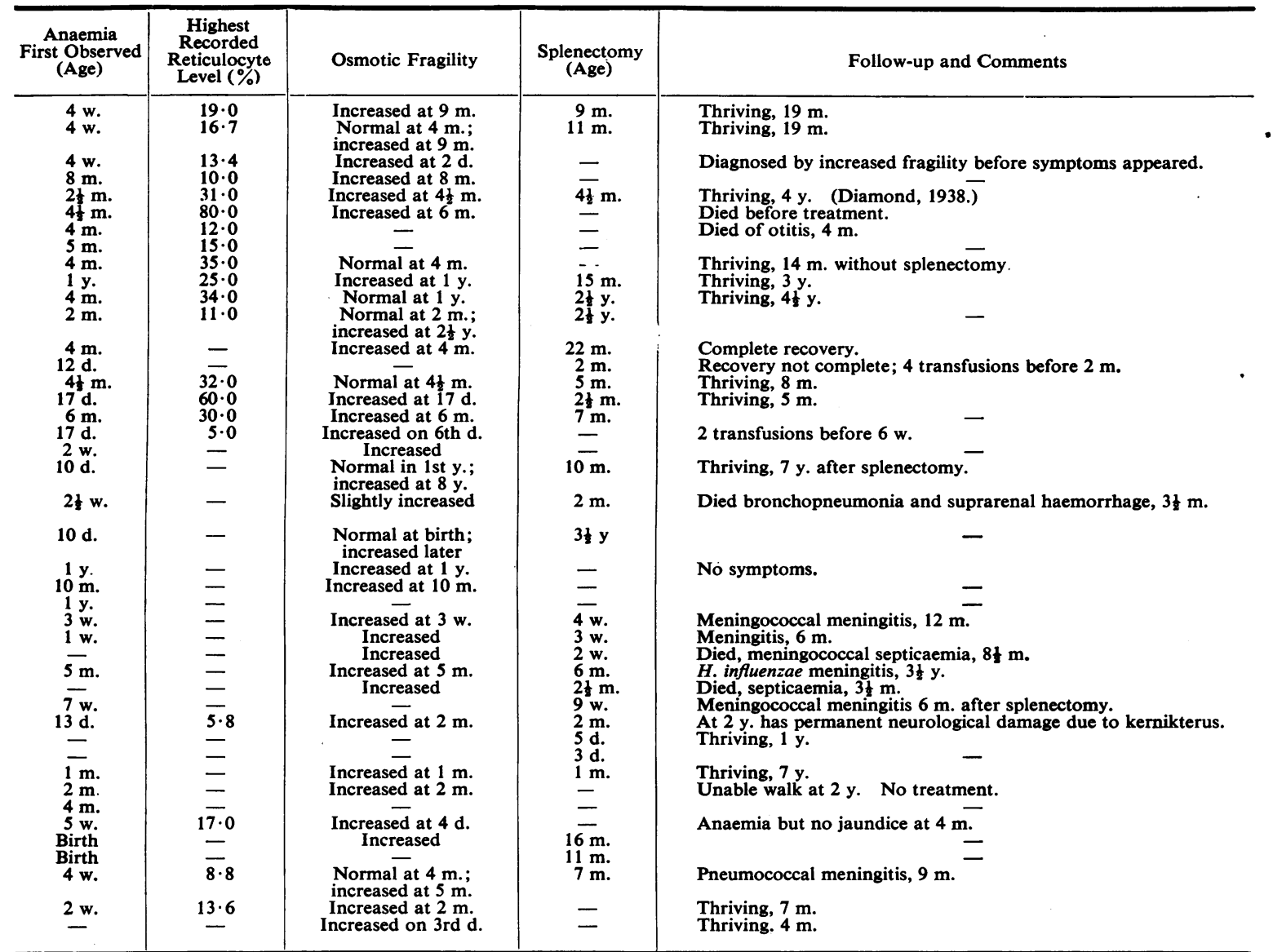

Exchange transfusion on 4th day.

reticulocytosis was marked and in the second case of Diamond (1937) it reached $80 \%$. This was often accompanied by normoblastaemia which reached $40 \%$ of total nucleated cells in Case 5 . The spherocytes can usually be identified in blood films stained with a Romanowsky dye as small deeply staining cells and the presence of larger thinner reticulocytes produces the anisocytosis and polychromasia which are frequently observed. In cases of congenital spherocytosis the mean cell diameter and the mean cell volume are smaller than usual, and the mean cell thickness is greater than normal. The changes, however, are usually not sufficiently abnormal to be of aid in substantiating the diagnosis (Young, Izzo and Platzer, 1951).

The osmotic fragility of the red blood cells was recorded in 34 cases and was normal in three cases and increased in the other 31. In five of these 31 cases the fragility was normal when first examined and increased later. In nine of the 26 cases with increased fragility on the first examination, the increase was noted in the first month of life. It is thus probably untrue that the red cell fragility may not be abnormal in infancy (David and Minot, 1944) but to demonstrate the abnormality may require a more careful technique including incubated red cell fragility, auto-haemolysis and mechanical fragility. These techniques are discussed by Young et al. (1951), and Robinson (1957) has found the incubated fragility increased at 4 months of age when the non-incubated fragility was within normal limits. The presence of spherocytes and an increased osmotic fragility in the neonatal period may, however, be associated with 
erythroblastosis foetalis due to $\mathrm{ABO}$ incompatibility (Crawford, Cutbush and Mollison, 1953).

The twins reported in this paper demonstrated all of the features which have been shown above to be typical of congenital spherocytosis in infancy. Although there was no family history of spherocytosis, the fact that both identical twins were affected strongly suggests that the disorder was a congenital one. They developed neonatal jaundice and subsequently a recurrent anaemia without jaundice. Their spleens were enlarged and blood examination showed the presence of spherocytes, reticulocytes and normoblasts, and the osmotic fragility of the cells was increased. Splenectomy dramatically relieved the recurring anaemia although the fragility of the red cells remained abnormal.

\section{Management}

Spencer Wells performed the first splenectomy in a case of congenital spherocytosis in 1887. Forty years later Dawson (1931) was able to make the diagnosis in retrospect by demonstrating the typical haematological picture in Spencer Wells' patient who was then completely symptom free. This demonstrates the effectiveness of the operation and today most authorities agree with Dacie (1954b) that the results of operation are so good and the mortality so low that the operation should be carried out in all patients except in the completely compensated and symptom-free cases. There are some who would go further (e.g. Young, 1955) and advise splenectomy even in the absence of symptoms.

However, recently evidence has accumulated to show that splenectomized children and infants have an increased susceptibility to infection, particularly to pneumococcal meningitis (Smith, Erlandson, Schulman and Stern, 1957). King and Shumacker (1952) thought that this association was restricted to children in the first 6 months of life, but the patients described by Smith et al. (1957) ranged in age from 13 months to 17 years at the time of splenectomy. Eight of the 21 children in Table 1 who had a splenectomy in the first year of life developed a serious infection post-operatively, and three of these died. Walter and Chaffin (1955) mention 10 cases of congenital spherocytosis treated in the first year of life by splenectomy and the only post-operative infection was a case of otitis media. Gofstein and Gellis (1956) discuss 17 cases of splenectomy for congenital spherocytosis under the age of 1 year and only one of their patients developed an infection, a fatal tracheo-bronchitis. By totalling from these three sources the incidence of infection following splenectomy for congenital spherocytosis in the first year of life, we find that $10,21 \%$, of 48 patients developed an infection and $4,8 \%$, died (Table 2). I have only been able to find one

TABLE 2

INCIDENCE OF INFECTIONS FOLLOWING SPLENECTOMY PERFORMED IN THE FIRST YEAR OF LIFE FOR CONGENITAL SPHEROCYTOSIS

\begin{tabular}{|c|c|c|c|c|}
\hline \multicolumn{2}{|r|}{ Source } & $\begin{array}{l}\text { No. of } \\
\text { Cases }\end{array}$ & $\begin{array}{l}\text { No. of } \\
\text { Infections }\end{array}$ & $\begin{array}{l}\text { No. of } \\
\text { Deaths due } \\
\text { to Infection }\end{array}$ \\
\hline Table 1 & .. & 21 & 8 & 3 \\
\hline Walter an & dd Chaffin (1955) & 10 & 1 & 0 \\
\hline Gofstein & and Gellis (1956) & 17 & 1 & 1 \\
\hline Total & $\ldots$ & $\begin{array}{c}48 \\
(100 \%)\end{array}$ & $\begin{array}{c}10 \\
(21 \%)\end{array}$ & $(8 \%)$ \\
\hline
\end{tabular}

record of a patient developing an infection after splenectomy for this disease later in life (Gofstein and Gellis, 1956). As far as present knowledge allows any conclusion to be made, the risk of infection following splenectomy in congenital spherocytosis appears to be confined to infancy, but it must be emphasized that this age distribution is not the experience of Smith et al. (1957) with splenectomy performed for other conditions. Although the evidence is by no means conclusive, it is probably wise to delay splenectomy as long as possible when congenital spherocytosis occurs in infancy. The management then resolves itself into the treatment of neonatal jaundice and anaemia later in infancy.

The prevention of kernikterus is the aim of treatment in the first week of life. This is liable to occur whenever the serum bilirubin rises above $19 \mathrm{mg}$. per $100 \mathrm{ml}$. in cases of haemolytic disease of the newborn (Mollison and Cutbush, 1951). It is, therefore, usual to perform a second or subsequent replacement transfusion whenever the serum bilirubin rises above $20 \mathrm{mg}$. per $100 \mathrm{ml}$. and if this technique is carried out kernikterus can be prevented (Hsia, 1953). Replacement transfusion was performed in Cases 33, 38 and 43 in Table 1, but in Case 38 evidence of kernikterus was already present. In Case 33 splenectomy was performed soon after the replacement transfusion and produced a rapid fall in the serum bilirubin and in Case 34 splenectomy was performed on the third day to prevent neonatal jaundice rising to a dangerous level. Smith and Franklin (1957) performed a replacement transfusion on both the third and fourth days of life and at 4 months their infant was symptom-free. Repeated exchange transfusions whenever the serum bilirubin is approaching or above $20 \mathrm{mg}$. per $100 \mathrm{ml}$. appears 
to be the treatment of choice in the hope that splenectomy may be delayed until after infancy.

If the patient presents as anaemia in infancy, then he must be carefully observed and blood transfusion advised whenever the haemoglobin level falls too low. The indication used in treating the twins was a haemoglobin level lower than $50 \%$ $(7.4 \mathrm{~g}$. per $100 \mathrm{ml}$.) and this prevented the development of cardiac dilatation and impairment of growth which was noted by Bernard et al. (1952). In these circumstances, the risks of delaying splenectomy are the development of pigment gall stones (but this has never been found in the first year of life) and the possible occurrence of a haemolytic or aplastic crisis. If the parents are advised to return to the clinic if the patient is pyrexial or unwell in any way, then the crisis can be diagnosed early and blood transfusion is likely to be life saving (Dameshek, 1941). Repeated blood transfusions will eventually lead to transfusion siderosis and this was noticed in the histological examination of the spleens of the twins in whom three transfusions each were given and splenectomy was performed at 9 and 11 months respectively.

\section{Summary}

Identical twins suffering from congenital spherocytosis in the first year of life are described and their clinical features, together with those of another 41 cases found in the literature, are tabulated.

The majority of cases occurring in infancy are found to have a positive family history and present as neonatal jaundice or recurring anaemia with an enlarged spleen. The characteristic changes in the peripheral blood are the presence of spherocytosis, a marked reticulocytosis and an increased red cell fragility.

Because of the risk of infection, splenectomy should be postponed until after infancy. Neonatal jaundice should be treated by repeated replacement transfusions and anaemia of infancy by simple blood transfusion.
I wish to thank Dr. A. Doyne Bell and Dr. C. T. Potter for permission to publish these cases and for their helpful criticisms and advice. I also wish to thank Dr. Sydney Shaw and the staff of the Department of Clinical Pathology for most of the haematological investigations, and Dr. John Shore for the pathology report on the spleens. Figure 1 was kindly produced by Miss P. M. Turnbull of the Photographic Department.

\section{REFERENCES}

Abt, A. F. (1940). Amer. J. Dis. Child., 60, 812.

Bernard, J., Boiron, M. and Estager, J. (1952). Sem. Hôp. Paris, 28,3741 .

Betke, K'. (1956). Z. Kinderheilk., 78, 359

Campbeli, J. M. H. and Warner, E. C. (1926). Quart. J. Med., 19, 333.

Conrad, E. and Schmidt, R. E. (1946). Amer. J. Dis. Child., 72, 731.

Crawford, H., Cutbush, M. and Mollison, P. L. (1953). Blood, 8, 620.

Dacie, J. V. (1954a). The Haemolytic Anaemias, p. 54. London.

- (1954b). Ibid., p. 73.

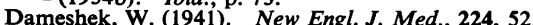

David, J. K., jr. and Minot, A. S. (1944). Amer. J. Dis. Child., 68, 327.

Dawson of Penn, Lord (1931). Brit. med. J., 1, 921.

Debré, R., Lamy, M., Sée, G. and Schrameck, G. (1938). Amer. J. Dis. Child., 56, 1189 .

Diamond, L. K. (1937). Med. Clin. N. Amer., 21, 401.

- (1938). Amer. J. Surg., 39,400.

Edwards, W. M. and Heaton, L. D. (1955). Amer. Practit. Dig. Treat., 6, 387.

Evans, T. S., Waters, L. L. and Lowman, R. M. (1954). Conn. med. $J ., 18,569$.

Fallon, M. (1943). J. Pediat., 23, 721.

Field, C. E. and Tan, E. E. (i955). Med. J. Malaya, 10, 60.

Gofstein, R. and Gellis, S. S. (1956). A.M.A. Amer. J. Dis. Child., 91, 566.

Hawksley, J. C. (1934). Proc. roy. Soc. Med., 27, 942.

Hindman, S. (1954). J. Pediat., 44, 213.

Hsia, D. Y. (1953). A.M.A. Amer. J. Dis. Child., 86, 484.

Josephs, H. W. (1938). Bull. Johns Hopk. Hosp., 62, 25.

King, H. and Shumacker, H. B. (1952). Ann. Surg., 136, 239.

Lappin, P. J. (1956). R. I. med. J., 39, 79.

Leffler, R. J. (1952). Amer. J. Path., 28, 303.

Lesné, E., Launay, C. and Hurez, -. (1935). Bull. Soc. Pédiat. Paris, 33, 445 .

Macaulay, D. (1951). Arch. Dis. Childh., 26, 241.

Mollison, P. L. and Cutbush, M. (1951). Blood, 6, 777.

Newns, G. (1951). Gt Ormond Str. J., i, 32.

Pinckney, C. (1946). Proc. roy. Soc. Med., 39, 696

Robinson, G. C. (1957). J. Pediat., 50, 446 .

Shapiro, C. M., Josephson, A. M., Rozengvaig, S. and Kauffman, A. (1957). Ibid., 50, 308.

Smith, C. H., Erlandson, M., Schulman, I. and Stern, G. (1957). Amer. $J$. Med 22, 390 .

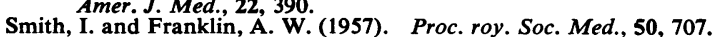

Smith, I. and Franklin, A. W. (1957). Proc. roy. Soc. Med., 50, 707.
Stenstrom, J. D. and Ford, H. S. (1956). Canad. med. Ass. J., 74, 34.

Thompson, W. P. (1936). J. Amer. med. Ass., 107, 1776.

Turman, C. M., Vaughan, V. C. and Shelly, R. M. (1956). Amer. J. Obstet. Gynec., 71, 885 .

Walter, L. E. and Chaffin, L. (1955). Ann. Surg., 142, 798

Young, L. E. (1955). Amer. J. Med., 18, 486.

, Izzo, M. J. and Platzer, R. F. (195i). Blood, 6, 1073. 